\title{
Effects of Ultra-High Pressure Homogenization on the Cheese-Making Properties of Milk
}

\author{
A. Zamora, V. Ferragut, P. D. Jaramillo, B. Guamis, and A. J. Trujillo ${ }^{1}$ \\ Centre Especial de Recerca Planta Tecnologia dels Aliments (CERPTA), Departament de Ciència Animal i dels Aliments, Facultat de \\ Veterinària, Universitat Autònoma de Barcelona, 08193 Bellaterra, Spain
}

\begin{abstract}
The effects of single- or 2-stage ultra-high pressure homogenization (UHPH; 100 to $330 \mathrm{MPa}$ ) at an inlet temperature of $30^{\circ} \mathrm{C}$ on the cheese-making properties of bovine milk were investigated. Effects were compared with those from raw, heat-pasteurized $\left(72^{\circ} \mathrm{C}\right.$ for $\left.15 \mathrm{~s}\right)$, and conventional homogenized-pasteurized $(15+3$ $\mathrm{MPa}, 72^{\circ} \mathrm{C}$ for $15 \mathrm{~s}$ ) treatments. Rennet coagulation time, rate of curd firming, curd firmness, wet yield, and moisture content of curds were assessed. Results of particle size and distribution of milk, whey composition, and gel microstructure observed by confocal laser scanning microscopy were analyzed to understand the effect of UHPH. Single-stage UHPH at 200 and $300 \mathrm{MPa}$ enhanced rennet coagulation properties. However, these properties were negatively affected by the use of the UHPH secondary stage. Increasing the pressure led to higher yields and moisture content of curds. The improvement in the cheese-making properties of milk by UHPH could be explained by changes to the proteinfat structures due to the combined effect of heat and homogenization.
\end{abstract}

Key words: ultra-high pressure homogenization, milk, rennet coagulation, cheese-making properties

\section{INTRODUCTION}

Research on technological processes on food is focused on 2 main goals: improving safety and quality of final products, and changing the characteristics of raw materials to obtain value-added products. However, processinduced modifications can have both beneficial and detrimental effects on technological aspects.

In dairy processes, thermal treatment of milk aims at increasing shelf life and improving food safety of the final product. Milk for cheese manufacture is generally pasteurized at $72^{\circ} \mathrm{C}$ typically for 15 to $35 \mathrm{~s}$. Higher temperatures have adverse effects on curd formation,

Received July 20, 2006.

Accepted August 31, 2006.

${ }^{1}$ Corresponding author: toni.trujillo@uab.es namely longer coagulation times and weaker gels (Guinee et al., 1997; Singh and Waungana, 2001), and on curd syneresis; that is, higher moisture content (Walstra et al., 1985; Pearse and Mackinlay, 1989; Rynne et al., 2004). Nevertheless, the effect of high heat treatment has received considerable attention owing to its potential for improving cheese yield through incorporation of whey proteins into cheese curd (Lucey, 1995; Singh and Waungana, 2001).

Conventional homogenization, developed by Gaulin in 1899 , has been widely adopted by the dairy industry. Homogenization is usually performed at $60^{\circ} \mathrm{C}$, and the milk is processed to break milk fat globules into fine lipid droplets, preventing cream separation, thereby increasing stability and shelf life of milk emulsion. Twostage homogenization is commonly used, in which the primary stage reduces the size of fat globules and the secondary stage disrupts clusters that may be formed. Although homogenization of whole milk has detrimental effects on curd forming properties (Emmons et al., 1980) and curd syneresis (Humbert et al., 1980; Green et al., 1983), it improves rennet action (Humbert et al., 1980; Robson and Dalgleish, 1984) and increases cheese yield due to better fat recovery (Jana and Upadhyay, 1992).

In recent years, homogenization equipment design has been modified to achieve far greater pressures. Although the principle of ultra-high pressure homogenization (UHPH) is similar to that of conventional balland-seat homogenizers, current developments in the design (e.g., the Stansted valve) allow homogenization at pressures of up to $350 \mathrm{MPa}$. Forces encountered during UHPH include cavitation, friction, turbulence, high velocity, and shear (Floury et al., 2004a,b), and result in the heating of the homogenized liquid (Floury et al., 2000; Hayes and Kelly, 2003a; Thiebaud et al., 2003). Applications of high-pressure homogenization are mainly found in the pharmaceutical and biotechnology sectors where the technique is used to emulsify, disperse, and mix (Floury et al., 2000). However, there has been increasing interest in its application in food technology. Reports on the effect of UHPH on some pathogenic and spoilage microorganisms in model and real food systems have proved its efficiency in reducing 
microbial counts (Hayes and Kelly, 2003a; Thiebaud et al., 2003; Hayes et al., 2005; Briñez et al., 2006). Moreover, studies with whole and skimmed milk have shown that UHPH produces fine emulsion particles (Hayes and Kelly, 2003a; Thiebaud et al., 2003; Hayes et al., 2005), modifies protein structure and characteristics (Hayes and Kelly, 2003a; Hayes et al., 2005; Sandra and Dalgleish, 2005), and inactivates enzymes (Hayes and Kelly, 2003b; Datta et al., 2005), all of which could have indirect effects on the coagulation properties of milk and the microstructural properties of cheese.

At the present time, data to describe the technological aptitude of milk treated by UHPH are scarce. The aim of this work was to determine the effect of UHPH treatment on the cheese-making properties of milk by comparing this new technology with pasteurization and conventional homogenization-pasteurization treatments.

\section{MATERIALS AND METHODS}

\section{Supply and Treatment of Milk}

Raw whole bovine milk was obtained from a local dairy farm (S.A.T. Can Badó, Roca del Vallès, Spain). Milk was standardized at $3.5 \pm 0.2 \%$ fat and kept overnight at $4^{\circ} \mathrm{C}$. Before all treatments, the milk was warmed to approximately $20^{\circ} \mathrm{C}$.

Ultra-high pressure homogenization was carried out by subjecting milk to single- or 2-stage UHPH (100, 200 , and $300 \mathrm{MPa}$ on the primary valve and $30 \mathrm{MPa}$ on the secondary valve) using a Stansted high-pressure homogenizer (model FPG11300, Stansted Fluid Power Ltd., Essex, UK) at an inlet temperature of $30 \pm 1^{\circ} \mathrm{C}$. This homogenizer comprises a high pressure valve made of ceramics able to support $350 \mathrm{MPa}$ and a second pneumatic valve able to support up to $50 \mathrm{MPa}$ located behind the first one. The high-pressure system consisted of 2 intensifiers driven by a hydraulic pump. The flow rate of milk in the homogenizer was $120 \mathrm{~L} / \mathrm{h}$. The inlet temperature of milk was kept at $30^{\circ} \mathrm{C}$ by a heat exchanger located behind the feeding tank. Temperature thermocouples and pressure gauges placed at the 2 valves measured temperature and pressure changes during processing. Throughout the experiment, the range of milk temperature was 33 to $41^{\circ} \mathrm{C}$ at the primary valve and 54 to $94^{\circ} \mathrm{C}$ at the secondary valve. To minimize temperature retention after treatment, 2 spiral-type heat exchangers (Garvía S.A., Barcelona, Spain) located behind the second valve were used. The outlet temperature of milk never exceeded $40^{\circ} \mathrm{C}$.

Milks from UHPH treatments were compared with raw and heat-treated milks. Pasteurized milk $\left(72^{\circ} \mathrm{C}\right.$ for $15 \mathrm{~s})$ and homogenized-pasteurized milk (15 MPa + 3 $\mathrm{MPa}$ at 57 to $60^{\circ} \mathrm{C}, 72^{\circ} \mathrm{C}$ for $15 \mathrm{~s}$ ) were chosen as typical treatments of cheese milk in different cheese varieties (fresh or ripened). Two-stage homogenization and pasteurization of raw milk were performed with a Niro Soavi homogenizer (model X68P Matr. 2123, Niro Soavi, Parma, Italy) and a Finamat heat exchanger (model 6500/010, GEA Finnah GmbH, Ahaus, Germany), respectively.

The complete experiment was repeated on 3 independent occasions.

\section{Particle Size and Distribution}

The particle size distribution in milk samples was determined using a Beckman Coulter laser diffraction particle size analyzer (LS 13320 series, Beckman Coulter, Fullerton, CA). Milk samples were diluted in distilled water until an appropriated obscuration was obtained in the diffractometer cell. An optical model based on the Mie theory of light scattering by spherical particles was applied by using the following conditions: real refractive index, 1.471; refractive index of fluid (water), 1.332; imaginary refractive index, 0; pump speed, $21 \%$. The diameter below which $90 \%$ of the volume of particles are found $\left(\mathbf{D}_{\mathbf{v}} \mathbf{0 . 9}\right)$, the diameter below which $50 \%$ of the volume of particles are found $\left(\mathbf{D}_{\mathbf{v}} \mathbf{0 . 5}\right)$, the volume-weighted mean diameter $[\mathbf{D}(\mathbf{4 , 3})]$, and the surface-weighted mean diameter $[\mathbf{D}(\mathbf{3 , 2})]$ were determined.

\section{Rennet Coagulation Properties}

Milk was warmed to $32^{\circ} \mathrm{C}$, and recombinant rennet (chymosin with a declared activity of 180 International Milk Clotting Units/mL, Maxiren 180, DSM Food Specialties, Seclin Cedex, France) was added at $0.074 \%$ ( vol/vol). Coagulation was carried out at $32^{\circ} \mathrm{C}$ for 30 min. Rennet coagulation properties [rennet coagulation time (RCT), rate of curd firming (RCF), and curd firmness at $30 \mathrm{~min}(\mathbf{C F})]$ were assessed in triplicate by the Optigraph system (Ysebaert Inc., Frepillon, France). This device passes an infrared beam through a sampling tube containing milk. A sensor on the other side measures the amount of light absorbed by the milk as it coagulates; the changes are analyzed in real time by a computer that converts them into directly usable data.

\section{Evaluation of Yield and Moisture Content of Curds}

The potential yield of cheese curd was estimated in quadruplicate as described by Macheboeuf et al. (1993). Milk samples $(270 \mathrm{~mL})$ were warmed to $32^{\circ} \mathrm{C}$ and recombinant rennet (chymosin with a declared activity of 180 International Milk Clotting Units/mL, Maxiren 180, DSM Food Specialties) at $0.074 \%$ (vol/vol) was 
added. Portions of the renneted milks ( $30 \mathrm{~g}$ ) were transferred into centrifuge tubes and allowed to coagulate at $32^{\circ} \mathrm{C}$ for $30 \mathrm{~min}$. The coagulum was centrifuged at $13,000 \times g$ for $15 \mathrm{~min}$ at $10^{\circ} \mathrm{C}$. Wet yield of curds, expressed as grams of retained curd per one hundred grams of milk, was determined by weighing the obtained pellets.

Curds were analyzed in duplicate for TS content (IDF, 1987) to calculate their moisture content (100 - TS) and the yield of total curd solids (wet yield $x$ $\mathrm{TS} / 100)$.

\section{Whey Composition: Total N, Whey Proteins, and Minerals Content}

The total $\mathrm{N}$ content of whey was analyzed in duplicate by the Dumas combustion method (IDF, 2002).

Reversed-phase HPLC analysis of rennet whey was performed using an automated system (LCM1, Waters Corporation, Milford, MA). Separations were carried out in a $250-\times 4.6-\mathrm{mm}$ column packed with C8-bonded silica gel with a particle diameter of $5 \mu \mathrm{m}$ and pore width of 3,000 nm (Tracer Excel, Teknokroma, Sant Cugat del Vallès, Spain) at a constant temperature of $40^{\circ} \mathrm{C}$, following the method of Resmini et al. (1989). Residual levels of $\alpha$-LA and $\beta$-LG were measured as total area of the respective peaks.

Calcium, $\mathrm{Mg}$, and $\mathrm{P}$ in whey were determined in triplicate by inductively coupled plasma optical emission spectroscopy with a Perkin-Elmer inductively coupled plasma spectroscopy unit (model 4300, Perkin-Elmer, Shelton, CT) with axial plasma viewing. The spectroscopy operating conditions were as follows: power $=1.3$ $\mathrm{kW}$; argon plasma flow rate $=15 \mathrm{~L} / \mathrm{min}$; argon auxiliary flow rate $=0.2 \mathrm{~L} / \mathrm{min}$; argon nebulizer flow rate $=0.74$ $\mathrm{L} / \mathrm{min}$; sample uptake rate $=1.5 \mathrm{~mL} / \mathrm{min}$; wavelengths (nm) for Ca, $\mathrm{P}$, and $\mathrm{Mg}=317.925,213.611$, and 285.213, respectively. Whey samples of $1 \mathrm{~mL}$ were transferred to a $25-\mathrm{mL}$ volumetric flask and nitric acid and deionized water were added to reach a final concentration of $0.2 \%$ (vol/vol) nitric acid. Standard solutions from $1 \mathrm{mg} / \mathrm{mL}$ stock solution of $\mathrm{Ca}, \mathrm{P}$, and $\mathrm{Mg}$ were used to prepare the calibration curves.

\section{Confocal Laser Scanning Microscopy of Rennet Gels}

Confocal laser scanning microscopy observations were performed in fluorescence mode essentially as Michalski et al. (2002) described. The protein matrix of renneted milks was stained by the fluorescent dye, fluorescein isothiocyanate (FITC; Fluka, Steinheim, Germany), and the fat globules were stained by Nile red (Sigma, Steinheim, Germany). The FITC and Nile red were dissolved in ethanol at a concentration of 2 and $1 \mathrm{mg} / \mathrm{mL}$, respectively. Milks $\left(10 \mathrm{~mL}\right.$ ) warmed at $32^{\circ} \mathrm{C}$ were dyed with 2 drops of FITC and 3 drops of Nile red. Recombinant rennet (Maxiren 180, DSM Food Specialties) at a concentration of $0.074 \%$ ( $\mathrm{vol} / \mathrm{vol}$ ) was added to the dyed milks. Then, 3 to 4 drops of the labeled renneted milks were transferred to microscope slides with concave cavities, covered with a coverslip, sealed to prevent evaporation, and incubated in a temperaturecontrolled incubator at $30^{\circ} \mathrm{C}$ for $30 \mathrm{~min}$. The preparations were cooled and kept at $4^{\circ} \mathrm{C}$ for a maximum of $3 \mathrm{~h}$.

The confocal microscope (Leica TCS SP2 AOBS, Heidelberg, Germany) was equipped with an oil-coupled Leica objective with a $63 \times$ augmentation and a numerical aperture of 1.4. Fluorescence from the samples was excited with the $488 \mathrm{~nm}$ line of an argon laser. Images were acquired in 2 channels simultaneously ( 501 to 549 $\mathrm{nm}$ and 574 to $626 \mathrm{~nm}$ ) as $1,024 \times 1,024$ pixel slices in the horizontal $x-y$ plane along the $z$ plane at constant gain and offset. Three-dimensional images were obtained by the average projection of 4 slices with Leica software.

\section{Statistical Analysis}

Data were processed by ANOVA using the GLM procedure of Statgraphics (Statgraphics, Inc., Chicago, IL). Tukey's test was used for comparison of sample data. Evaluations were based on a significance level of $P<$ 0.05 .

\section{RESULTS}

\section{Particle Size and Distribution}

Four parameters $\left[\mathrm{D}_{\mathrm{v}} 0.9, \mathrm{D}_{\mathrm{v}} 0.5, \mathrm{D}(4,3)\right.$, and $\left.\mathrm{D}(3,2)\right]$ as well as the distribution patterns were taken into consideration to see the effects of UHPH on particle size and distribution (Table 1).

The size distribution of particles in raw milk was characterized by a main peak at $3.8 \mu \mathrm{m}$ and a second lower peak around $0.2 \mu \mathrm{m}$, which corresponded to fat globules and casein micelle particles, respectively. Pasteurized milk showed a similar pattern. As expected, the size distribution of homogenized milks changed markedly; their main peaks were between 0.1 and 0.3 $\mu \mathrm{m}$ for UHPH-treated milks, and approximately 0.4 $\mu \mathrm{m}$ for homogenized-pasteurized milk. Samples undergoing UHPH treatment at $330 \mathrm{MPa}$ showed a second peak, lower but much wider at $4.6 \mu \mathrm{m}$ with a shoulder at approximately $11.9 \mu \mathrm{m}$.

Significant differences $(P<0.05)$ between pasteurized and raw milks were found for $\mathrm{D}_{\mathrm{v}} 0.5$ and $\mathrm{D}(3,2)$. Homogenized-pasteurized samples showed values between those of pasteurized and raw milks, on one side, and 
Table 1. Particle size ( $\mu \mathrm{m})$ of raw, pasteurized, homogenized-pasteurized, and ultra-high pressure homogenized (UHPH) milks ${ }^{1}$

\begin{tabular}{lllll}
\hline Treatment $^{2}$ & $\mathrm{D}_{\mathrm{v}} 0.9$ & $\mathrm{D}_{\mathrm{v}} 0.5$ & $\mathrm{D}(4,3)$ & $\mathrm{D}(3,2)$ \\
\hline Raw & $5.07 \pm 0.03^{\mathrm{b}}$ & $3.11 \pm 0.04^{\mathrm{b}}$ & $2.90 \pm 0.05^{\mathrm{a}}$ & $0.63 \pm 0.03^{\mathrm{a}}$ \\
Pasteurized & $5.16 \pm 0.04^{\mathrm{b}}$ & $3.16 \pm 0.01^{\mathrm{a}}$ & $2.94 \pm 0.01^{\mathrm{a}}$ & $0.59 \pm 0.01^{\mathrm{b}}$ \\
Homogenized-pasteurized & $1.10 \pm 0.03^{\mathrm{c}}$ & $0.39 \pm 0.00^{\mathrm{c}}$ & $0.50 \pm 0.01^{\mathrm{c}}$ & $0.32 \pm 0.01^{\mathrm{c}}$ \\
UHPH (MPa) & & & \\
100 & $0.80 \pm 0.03^{\mathrm{d}}$ & $0.34 \pm 0.00^{\mathrm{d}}$ & $0.44 \pm 0.01^{\mathrm{cd}}$ & $0.28 \pm 0.01^{\mathrm{d}}$ \\
130 & $0.68 \pm 0.01^{\mathrm{de}}$ & $0.31 \pm 0.01^{\mathrm{e}}$ & $0.40 \pm 0.01^{\mathrm{d}}$ & $0.25 \pm 0.01^{\mathrm{e}}$ \\
200 & $0.43 \pm 0.01^{\mathrm{f}}$ & $0.21 \pm 0.02^{\mathrm{g}}$ & $0.25 \pm 0.02^{\mathrm{e}}$ & $0.19 \pm 0.02^{\mathrm{g}}$ \\
230 & $0.49 \pm 0.01^{\mathrm{ef}}$ & $0.25 \pm 0.01^{\mathrm{f}}$ & $0.31 \pm 0.03^{\mathrm{e}}$ & $0.21 \pm 0.01^{\mathrm{f}}$ \\
300 & $0.29 \pm 0.01^{\mathrm{f}}$ & $0.15 \pm 0.00^{\mathrm{h}}$ & $0.17 \pm 0.01^{\mathrm{f}}$ & $0.13 \pm 0.00^{\mathrm{h}}$ \\
330 & $5.82 \pm 0.35^{\mathrm{a}}$ & $0.25 \pm 0.01^{\mathrm{f}}$ & $2.01 \pm 0.14^{\mathrm{b}}$ & $0.22 \pm 0.01^{\mathrm{f}}$ \\
\hline
\end{tabular}

${ }^{\mathrm{a}-\mathrm{h}}$ Values without common superscripts were significantly different $(P<0.05)$.

${ }^{1}$ Mean value \pm standard error. Particle size parameters: $D_{\mathrm{v}} 0.9$ and $\mathrm{D}_{\mathrm{v}} 0.5=$ the diameters below which $90 \%$ and $50 \%$ of the volume of particles are found, respectively; $\mathrm{D}(4,3)=$ the volume-weighted mean diameter; and $\mathrm{D}(3,2)=$ the surface-weighted mean diameter.

${ }^{2}$ Pasteurized $\left(72^{\circ} \mathrm{C}\right.$ for $\left.15 \mathrm{~s}\right)$; homogenized-pasteurized $\left(15+3 \mathrm{MPa}\right.$ at 57 to $60^{\circ} \mathrm{C}, 72^{\circ} \mathrm{C}$ for $\left.15 \mathrm{~s}\right)$; UHPH treatments at 130, 230, and $330 \mathrm{MPa}$ made using 2-stage homogenization: 100, 200, and $300 \mathrm{MPa}$ in first valve and $30 \mathrm{MPa}$ in second valve.

those of UHPH-treated milks, on the other. Increasing the pressure of UHPH significantly decreased all 4 parameters, except for UHPH treatment at $330 \mathrm{MPa}$. Twostage homogenization did not affect either $\mathrm{D}_{\mathrm{v}} 0.9$ or $\mathrm{D}(4,3)$ at pressures below $300 \mathrm{MPa}$. However, above 100 $\mathrm{MPa}$, the 2-stage homogenized samples showed higher $\mathrm{D}_{\mathrm{v}} 0.5$ and $\mathrm{D}(3,2)$ values than their counterparts treated by single-stage homogenization. Milk samples UHPHtreated at $330 \mathrm{MPa}$ showed a $\mathrm{D}_{\mathrm{v}} 0.9$ value significantly higher than that of raw milk, and a $\mathrm{D}(4,3)$ value closer to that of raw milk than to UHPH-treated milks.

\section{Rennet Coagulation Properties}

Pasteurization did not affect $\mathrm{pH}$, but homogenizedpasteurized milk showed significantly lower $\mathrm{pH}$ than that of raw milk. The influence of UHPH on the $\mathrm{pH}$ highly depended on the applied pressure; below 300 $\mathrm{MPa}$, the values were significantly lower (Table 2).

Rennet coagulation times were very much dependent on the treatment, although 2-stage homogenization did not seem to affect it. Samples treated at 100 to 130 MPa had significantly lower RCT than raw milk. In the case of milk treated at 200 to $230 \mathrm{MPa}$, RCT were also significantly lower than that of raw milk but similar to that obtained with homogenized-pasteurized milk. On the other hand, the RCT of the samples treated at 300 to $330 \mathrm{MPa}$ were similar to those obtained with pasteurized and raw milks.

Two-stage homogenization in all UHPH treatments significantly $(P<0.05)$ diminished both RCF and CF in relation to their homologues treated by single stage. The values of RCF were either significantly lower or similar to those of raw milk. The UHPH treatments at 200 and $300 \mathrm{MPa}$ and heat pasteurization significantly increased RCF compared with raw milk. However, only the UHPH treatments at 200 and $300 \mathrm{MPa}$ resulted in significantly higher $\mathrm{CF}$ than raw milk.

\section{Curd Yield and Moisture Content}

Wet yields and moisture content of the curds obtained from the UHPH-treated milks were significantly greater than those of homogenized-pasteurized, pasteurized, and raw milks (Table 3). Increasing the pressure from 100 to $300 \mathrm{MPa}$ increased wet curd yield by approximately 33 to $65 \%$, and moisture content by approximately 11 to $18 \%$ compared with raw milk. Samples treated at $330 \mathrm{MPa}$ showed significantly lower values than samples treated at $300 \mathrm{MPa}$.

Conventional pasteurization and homogenizationpasteurization increased the yield of total curd solids by approximately 7\% compared with raw milk. For UHPHtreated milks, the increases were approximately 4,6 , $7,8,10$, and $11 \%$ at $130,100,200,230,330$, and 300 $\mathrm{MPa}$, respectively.

\section{Whey Composition}

All treatments significantly $(P<0.05)$ decreased the amount of total $\mathrm{N}$ in whey (Table 4). The UHPH samples showed a decrease of approximately 2 to $22 \%$ correlated to the increase of pressure. Above $200 \mathrm{MPa}$, the effect of UHPH was much higher than those of the pasteurization and homogenization-pasteurization treatments, although the 2-stage homogenized samples did not differ from their single-stage homologues. The same results were observed for $\beta$-LG content of whey (Table 4). For $\alpha$-LA, although no statistical differences were found between whey from raw, pasteurized, and homoge- 
Table 2. $\mathrm{pH}$ and rennet coagulation properties [rennet coagulation time (RCT), rate of curd firming (RCF), and curd firmness $(\mathrm{CF})]$ of raw, pasteurized, homogenized-pasteurized, and ultra-high pressure homogenized (UHPH) milks ${ }^{1}$

\begin{tabular}{lllll}
\hline Treatment $^{2}$ & $\mathrm{pH}$ & $\mathrm{RCT}(\mathrm{min})$ & $\mathrm{RCF}(\mathrm{mA} / \mathrm{min})$ & $\mathrm{CF}(\mathrm{mA})$ \\
\hline Raw & $6.75 \pm 0.01^{\mathrm{a}}$ & $7.43 \pm 0.13^{\mathrm{a}}$ & $1.37 \pm 0.04^{\mathrm{d}}$ & $13.33 \pm 0.27^{\mathrm{c}}$ \\
Pasteurized & $6.75 \pm 0.01^{\mathrm{a}}$ & $7.66 \pm 0.15^{\mathrm{a}}$ & $1.47 \pm 0.03^{\mathrm{c}}$ & $13.80 \pm 0.24^{\mathrm{bc}}$ \\
Homogenized-pasteurized & $6.72 \pm 0.01^{\mathrm{b}}$ & $6.91 \pm 0.15^{\mathrm{b}}$ & $0.99 \pm 0.04^{\mathrm{f}}$ & $10.21 \pm 0.16^{\mathrm{e}}$ \\
UHPH (MPa) & & & & \\
100 & $6.52 \pm 0.03^{\mathrm{e}}$ & $5.44 \pm 0.27^{\mathrm{c}}$ & $1.07 \pm 0.10^{\mathrm{e}}$ & $11.51 \pm 0.71^{\mathrm{d}}$ \\
130 & $6.51 \pm 0.03^{\mathrm{f}}$ & $5.18 \pm 0.27^{\mathrm{c}}$ & $0.77 \pm 0.07^{\mathrm{g}}$ & $10.32 \pm 0.54^{\mathrm{e}}$ \\
200 & $6.68 \pm 0.02^{\mathrm{d}}$ & $6.91 \pm 0.29^{\mathrm{b}}$ & $1.84 \pm 0.07^{\mathrm{a}}$ & $15.00 \pm 0.31^{\mathrm{a}}$ \\
230 & $6.69 \pm 0.01^{\mathrm{c}}$ & $7.02 \pm 0.09^{\mathrm{b}}$ & $1.32 \pm 0.05^{\mathrm{d}}$ & $11.99 \pm 0.27^{\mathrm{d}}$ \\
300 & $6.75 \pm 0.01^{\mathrm{a}}$ & $7.69 \pm 0.09^{\mathrm{a}}$ & $1.72 \pm 0.02^{\mathrm{b}}$ & $14.46 \pm 0.16^{\mathrm{ab}}$ \\
330 & $6.74 \pm 0.00^{\mathrm{a}}$ & $7.68 \pm 0.11^{\mathrm{a}}$ & $1.32 \pm 0.05^{\mathrm{d}}$ & $11.75 \pm 0.33^{\mathrm{d}}$ \\
\hline
\end{tabular}

${ }^{a-g}$ Values without common superscripts were significantly different $(P<0.05)$.

${ }^{1}$ Mean value \pm standard error.

${ }^{2}$ Pasteurized $\left(72^{\circ} \mathrm{C}\right.$ for $\left.15 \mathrm{~s}\right)$; homogenized-pasteurized $\left(15+3 \mathrm{MPa}\right.$ at 57 to $60^{\circ} \mathrm{C}, 72^{\circ} \mathrm{C}$ for $\left.15 \mathrm{~s}\right)$; UHPH treatments at 130, 230, and $330 \mathrm{MPa}$ made using 2-stage homogenization: 100, 200, and $300 \mathrm{MPa}$ in first valve and $30 \mathrm{MPa}$ in second valve.

nized-pasteurized milks, all UHPH treatments showed a significant decrease of $\alpha$-LA in whey compared with raw milk. Denaturation of $\beta$-LG was more important than that of $\alpha$-LA; levels were obtained of up to approximately $35 \%$ for $\beta$-LG at 300 and $330 \mathrm{MPa}$, and around $12 \%$ for $\alpha$-LA at $300 \mathrm{MPa}$.

Only the whey obtained from UHPH treatments performed at 100 to $130 \mathrm{MPa}$ and 300 to $330 \mathrm{MPa}$ had significantly higher or lower amounts, respectively, of all 3 mineral salts $(\mathrm{Ca}, \mathrm{P}$, and $\mathrm{Mg})$ compared with raw milk (Table 5). Whey from milk UHPH-treated at 200 $\mathrm{MPa}$ had higher amounts of $\mathrm{Ca}$ and $\mathrm{P}$ and a lower amount of $\mathrm{Mg}$ than that of raw milk. Whey from treated milk at $230 \mathrm{MPa}$ presented similar amounts of $\mathrm{Ca}$ and $\mathrm{Mg}$ and higher amounts of $\mathrm{P}$ than raw milk. Pasteurized

Table 3. Wet yield and moisture content of curds from raw, pasteurized, homogenized-pasteurized, and ultra-high pressure homogenized (UHPH) milks ${ }^{1}$

\begin{tabular}{lll}
\hline Treatment $^{2}$ & Wet yield $(\%)$ & $\begin{array}{l}\text { Moisture } \\
\text { content }(\%)\end{array}$ \\
\hline Raw & $21.38 \pm 0.38^{\mathrm{h}}$ & $64.76 \pm 0.22^{\mathrm{h}}$ \\
Pasteurized & $22.00 \pm 0.58^{\mathrm{i}}$ & $63.45 \pm 0.39^{\mathrm{i}}$ \\
Homogenized-pasteurized & $26.68 \pm 0.37^{\mathrm{g}}$ & $69.86 \pm 0.19^{\mathrm{g}}$ \\
UHPH $(\mathrm{MPa})$ & $28.39 \pm 0.57^{\mathrm{f}}$ & $71.92 \pm 0.22^{\mathrm{f}}$ \\
100 & $29.01 \pm 0.51^{\mathrm{e}}$ & $73.03 \pm 0.15^{\mathrm{e}}$ \\
130 & $31.47 \pm 0.76^{\mathrm{d}}$ & $74.35 \pm 0.24^{\mathrm{d}}$ \\
200 & $32.76 \pm 0.57^{\mathrm{c}}$ & $75.10 \pm 0.16^{\mathrm{c}}$ \\
230 & $35.35 \pm 0.71^{\mathrm{a}}$ & $76.42 \pm 0.09^{\mathrm{a}}$ \\
300 & $34.33 \pm 0.64^{\mathrm{b}}$ & $75.95 \pm 0.09^{\mathrm{b}}$ \\
330 &
\end{tabular}

${ }^{\mathrm{a}-\mathrm{i}}$ Values without common superscripts were significantly different $(P<0.05)$.

${ }^{1}$ Mean value \pm standard error.

${ }^{2}$ Pasteurized $\left(72^{\circ} \mathrm{C}\right.$ for $\left.15 \mathrm{~s}\right)$; homogenized-pasteurized ( $15+3 \mathrm{MPa}$ at 57 to $60^{\circ} \mathrm{C}, 72^{\circ} \mathrm{C}$ for $15 \mathrm{~s}$ ); UHPH treatments at 130,230 , and 330 MPa made using 2-stage homogenization: 100, 200, and $300 \mathrm{MPa}$ in first valve and $30 \mathrm{MPa}$ in second valve. and homogenized-pasteurized samples showed lower amounts of $\mathrm{Ca}$ and $\mathrm{Mg}$ and similar amounts of $\mathrm{P}$ compared with raw milk.

\section{Confocal Laser Scanning Microscopy of Rennet Gels}

Confocal micrographs of rennet gels revealed the existence of visual differences between treatments in the proteinaceous matrix and fat globule size as well as at their interaction (Figure 1).

Rennet gels from pasteurized milk were similar to those obtained from raw milk. The micrographs showed a porous structure of the casein network with native milk fat globules mainly located in the serum pores of the gels (results not shown).

When milk was homogenized-pasteurized, the rennet gels presented open matrices; serum pores were large, irregular, and delimited by thick and lumpy strands. Nile red fluorescence revealed that fat globules had different locations depending on their size (Figure 1a). The smallest fat globules $(<0.5 \mu \mathrm{m})$ became part of the proteinaceous network, explaining the thickness of the strands. The gels presented many strands that ended with midsized fat globules $(\sim 1 \mu \mathrm{m})$. Larger fat globules ( 1.5 to $2 \mu \mathrm{m})$, which accounted for a very small number, were retained in the serum pores.

Although UHPH treatments at $100 \mathrm{MPa}$ showed a greater amount of smaller fat globules and few larger globules ( 4 to $6 \mu \mathrm{m})$, the general aspect of the matrix was rather similar to that of homogenized-pasteurized milks (Figure 1b). The second stage at $100 \mathrm{MPa}$ reduced the size of the largest fat globules $(\sim 3 \mu \mathrm{m})$. Moreover, the structure of the gel was smoother with smaller pores. However, the smallest fat globules were also embedded within the proteinaceous network. 
Table 4. Total $\mathrm{N}$ content and residual $\alpha$-LA and $\beta$-LG (measured as total area $\times 10^{5}$ of the respective peaks) in whey of raw, pasteurized, homogenized-pasteurized, and ultra-high pressure homogenized (UHPH) milks ${ }^{1}$

\begin{tabular}{lllr}
\hline Treatment $^{2}$ & Total N $(\%)$ & $\alpha$-LA & $\beta$-LG \\
\hline Raw & $0.143 \pm 0.004^{\mathrm{a}}$ & $41.09 \pm 1.55^{\mathrm{a}}$ & $107.71 \pm 5.99^{\mathrm{a}}$ \\
Pasteurized & $0.135 \pm 0.005^{\mathrm{c}}$ & $40.52 \pm 1.52^{\mathrm{ab}}$ & $102.76 \pm 5.66^{\mathrm{b}}$ \\
Homogenized-pasteurized & $0.133 \pm 0.004^{\mathrm{d}}$ & $39.88 \pm 1.50^{\mathrm{abc}}$ & $94.65 \pm 4.82^{\mathrm{c}}$ \\
UHPH $(\mathrm{MPa})$ & & $38.41 \pm 0.56^{\mathrm{cd}}$ & $103.16 \pm 3.04^{\mathrm{b}}$ \\
100 & $0.140 \pm 0.004^{\mathrm{b}}$ & $38.43 \pm 0.39^{\mathrm{bcd}}$ & $103.88 \pm 4.06^{\mathrm{b}}$ \\
130 & $0.137 \pm 0.003^{\mathrm{c}}$ & $37.55 \pm 0.29^{\mathrm{de}}$ & $85.65 \pm 1.60^{\mathrm{d}}$ \\
200 & $0.125 \pm 0.001^{\mathrm{e}}$ & $36.75 \pm 0.72^{\mathrm{de}}$ & $86.25 \pm 1.30^{\mathrm{d}}$ \\
230 & $0.126 \pm 0.004^{\mathrm{e}}$ & $36.08 \pm 0.22^{\mathrm{e}}$ & $70.04 \pm 2.07^{\mathrm{e}}$ \\
300 & $0.112 \pm 0.003^{\mathrm{f}}$ & $36.86 \pm 0.42^{\mathrm{de}}$ & $69.28 \pm 1.86^{\mathrm{e}}$ \\
330 & $0.112 \pm 0.002^{\mathrm{f}}$ &
\end{tabular}

${ }^{a-f}$ Values without common superscripts were significantly different $(P<0.05)$.

${ }^{1}$ Mean value \pm standard error.

${ }^{2}$ Pasteurized $\left(72^{\circ} \mathrm{C}\right.$ for $\left.15 \mathrm{~s}\right)$; homogenized-pasteurized $\left(15+3 \mathrm{MPa}\right.$ at 57 to $60^{\circ} \mathrm{C}, 72^{\circ} \mathrm{C}$ for $\left.15 \mathrm{~s}\right)$; UHPH treatments at 130, 230, and $330 \mathrm{MPa}$ made using 2-stage homogenization: 100, 200, and $300 \mathrm{MPa}$ in first valve and $30 \mathrm{MPa}$ in second valve.

Micrographs of gels from single-stage treatments above $200 \mathrm{MPa}$ showed that Nile red fluorescence at the level of the proteinaceous network was markedly weaker (Figures $1 \mathrm{c}$ and d). Rennet gels from milk treated at $200 \mathrm{MPa}$ revealed tight matrices. It should be mentioned that micrographs from UHPH-treated milk at $300 \mathrm{MPa}$ not only had lower levels of Nile red fluorescence but also lower FITC fluorescence (Figure 1d).

The second stage above $200 \mathrm{MPa}$ provoked the coating of midsized fat globules; this phenomenon was more visible as the pressure at the first valve was increased. Moreover, the proteinaceous matrices, which were more lax than those of rennet gels from single-stage treated milks, were strongly stained by Nile red (Figures 1e and f). Two-stage UHPH treatment at $300 \mathrm{MPa}$ provoked the formation of spherical protein aggregates sur- rounding a large number of noncoated, midsized fat globules ( $2 \mu \mathrm{m}$; Figures $1 \mathrm{~g}$ and $\mathrm{h})$.

\section{DISCUSSION}

\section{Effects of Heat and Conventional Homogenization Treatments}

Mild heat treatments are considered to have no or little effect on the whey proteins of milk, although there are reports that heat pasteurization $\left(72^{\circ} \mathrm{C}\right.$ for $20 \mathrm{~s}$ or $73^{\circ} \mathrm{C}$ for $15 \mathrm{~s}$ ) could cause denaturation of approximately $7 \%$ of the whey protein fraction of milk (Jelen and Rattray, 1995). Our results showed that pasteurization heat treatment of $72^{\circ} \mathrm{C}$ for $15 \mathrm{~s}$ was sufficient to reduce $\sim 5 \%$ of the total $\mathrm{N}$ of whey, with levels of residual $\beta$-LG and $\alpha$-LA being $\sim 5$ and $1.4 \%$ lower, re-

Table 5. Whey composition in minerals of raw, pasteurized, homogenized-pasteurized, and ultra-high pressure homogenized (UHPH) milks ${ }^{1}$

\begin{tabular}{llll}
\hline & \multicolumn{3}{c}{ Minerals $(\mathrm{mg} / \mathrm{L})$} \\
\cline { 2 - 4 } Treatment $^{2}$ & $\mathrm{Ca}$ & $\mathrm{P}$ & $\mathrm{Mg}$ \\
\hline Raw & $377.33 \pm 9.17^{\mathrm{d}}$ & $435.07 \pm 3.12^{\mathrm{e}}$ & $88.24 \pm 1.66^{\mathrm{b}}$ \\
Pasteurized & $371.64 \pm 8.98^{\mathrm{e}}$ & $433.75 \pm 1.63^{\mathrm{e}}$ & $87.23 \pm 1.62^{\mathrm{cd}}$ \\
Homogenized-pasteurized & $372.23 \pm 9.16^{\mathrm{e}}$ & $436.17 \pm 2.65^{\mathrm{de}}$ & $86.91 \pm 1.65^{\mathrm{d}}$ \\
UHPH (MPa) & & $461.73 \pm 3.10^{\mathrm{b}}$ & $89.29 \pm 1.21^{\mathrm{a}}$ \\
100 & $393.12 \pm 7.61^{\mathrm{b}}$ & $471.16 \pm 4.79^{\mathrm{a}}$ & $90.04 \pm 1.17^{\mathrm{a}}$ \\
130 & $404.56 \pm 6.33^{\mathrm{a}}$ & $447.15 \pm 4.36^{\mathrm{c}}$ & $87.19 \pm 1.28^{\mathrm{cd}}$ \\
200 & $386.20 \pm 5.38^{\mathrm{c}}$ & $442.48 \pm 5.68^{\mathrm{cd}}$ & $87.91 \pm 1.72^{\mathrm{bc}}$ \\
230 & $381.21 \pm 12.47^{\mathrm{d}}$ & $414.91 \pm 7.09^{\mathrm{f}}$ & $83.52 \pm 1.64^{\mathrm{e}}$ \\
300 & $356.10 \pm 15.68^{\mathrm{g}}$ & $419.60 \pm 3.73^{\mathrm{f}}$ & $83.36 \pm 1.21^{\mathrm{e}}$ \\
\hline 30 & $361.33 \pm 9.95^{\mathrm{f}}$ &
\end{tabular}

${ }^{\mathrm{a}-\mathrm{f}}$ Values without common superscripts were significantly different $(P<0.05)$.

${ }^{1}$ Mean value \pm standard error.

${ }^{2}$ Pasteurized $\left(72^{\circ} \mathrm{C}\right.$ for $\left.15 \mathrm{~s}\right)$; homogenized-pasteurized $\left(15+3 \mathrm{MPa}\right.$ at 57 to $60^{\circ} \mathrm{C}, 72^{\circ} \mathrm{C}$ for $\left.15 \mathrm{~s}\right)$; UHPH treatments at 130, 230, and $330 \mathrm{MPa}$ made using 2-stage homogenization: 100, 200, and $300 \mathrm{MPa}$ in first valve and $30 \mathrm{MPa}$ in second valve. 
(a)

(c)
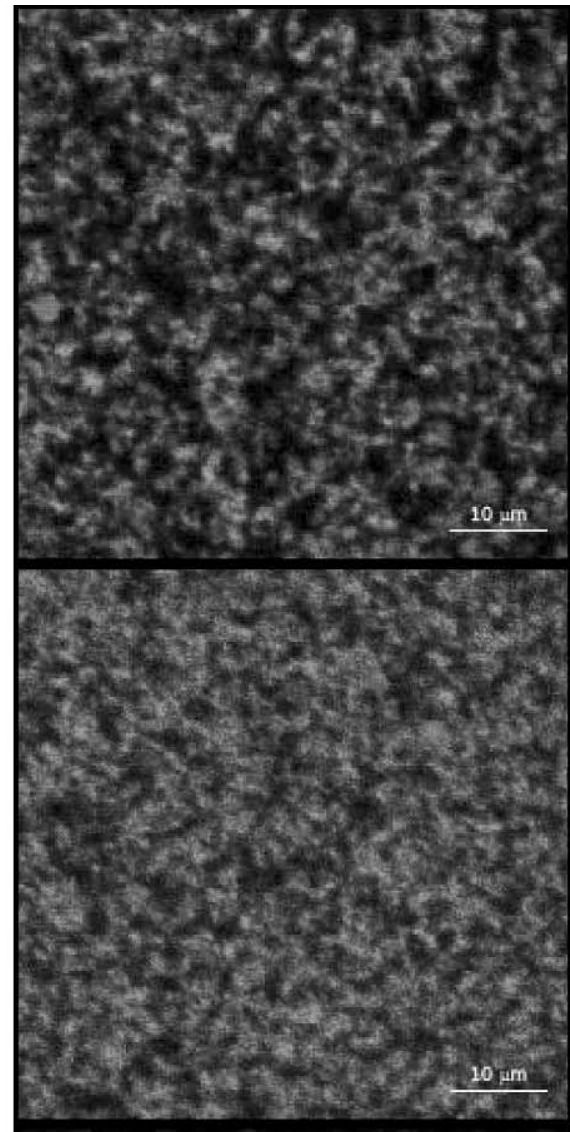

(e)

(g)

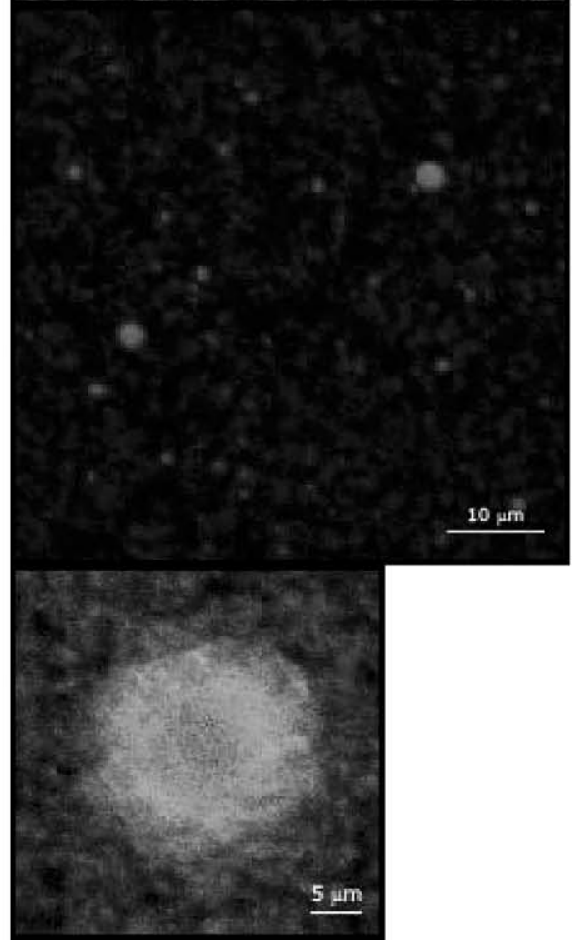

(b)

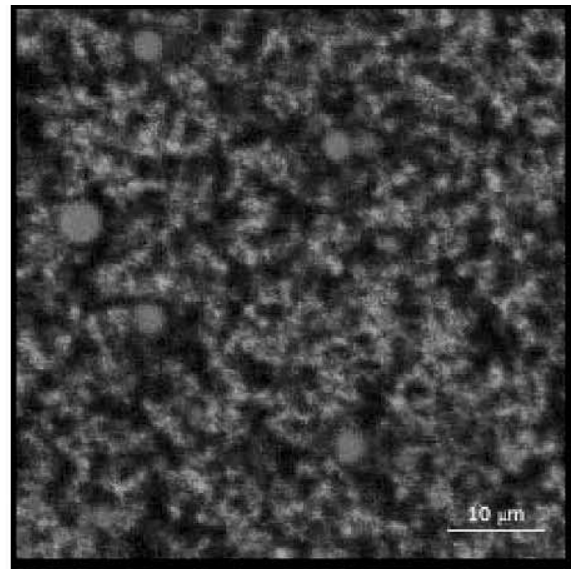

(d)

(f)
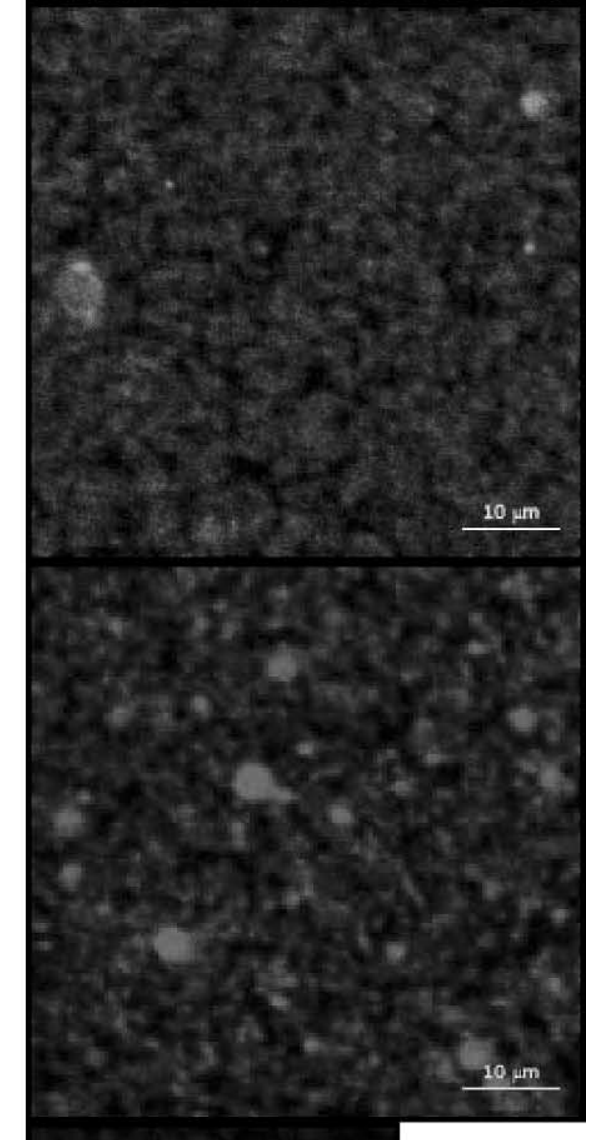

(h)

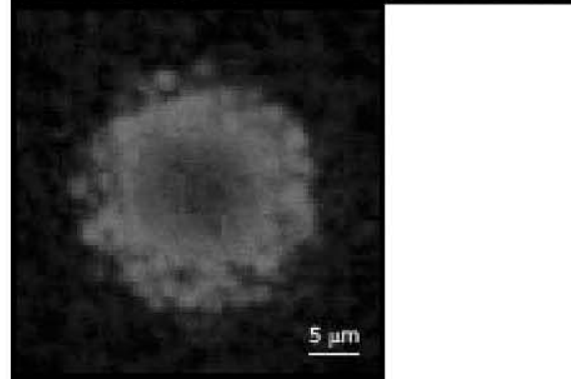

Figure 1. Confocal laser scanning micrographs of rennet curds from a) homogenized-pasteurized milk; ultra-high pressure homogenized (UHPH) milk at b) $100 \mathrm{MPa}$; c) $200 \mathrm{MPa}$; and d) $300 \mathrm{MPa}$; Nile red fluorescence (fat) from milk UHPH-treated at e) $200 \mathrm{MPa}$, and f) 230 $\mathrm{MPa}$; and aggregates of fat globules dyed with g) Nile red and fluorescein isothiocyanate, and h) Nile red. Color images are available online at http://jds.fass.org/. 
spectively, in whey from pasteurized milk compared with untreated milk.

Furthermore, heating has a marked effect on the milk salts equilibrium and their interaction with casein. It is generally agreed that heating leads to a decrease in diffusible calcium and inorganic phosphate, due to precipitation of calcium phosphate, which may be reversed depending on the intensity of the treatment (Gaucheron, 2005). Under our experimental conditions, the decrease of $\mathrm{Ca}, \mathrm{P}$, and $\mathrm{Mg}$ in whey from pasteurized milk suggests a mineral transfer from soluble to colloidal phase of milk.

Milk pasteurization has only minor effects on the formation and physical properties of rennet-induced milk gels (Lucey, 1995). In our study, pasteurized milk had no significantly different RCT and CF in relation to untreated milk. However, more severe heating conditions impair renneting milk properties (Dalgleish and Banks, 1991; Guinee et al., 1996, 1997; Singh and Waungana, 2001). The causes have been broadly investigated even though they are not yet fully understood. Both the enzymatic and nonenzymatic phases of rennet clotting are delayed and the RCT is longer than that of unheated milk. The strength of renneted milk gels is also adversely affected in heated milk. It has been established that when heated, $\beta$-LG and $\kappa$-casein form a complex by sulfydryl-disulfide interchange at the micelle surfaces that reduces the accessibility of the rennet to the $\kappa$-casein and provides steric hindrance to close approach and fusion of paracasein micelles. Moreover, heat induces the deposition of calcium phosphate and the consequent reduction in native calcium phosphate, which is important for cross-linking paracasein micelles.

Incorporation of denatured whey protein in the curd from pasteurized milk did not increase the moisture content of the curd compared with raw milk. However, the yield of TS of the curd from pasteurized milk was $\sim 7 \%$ higher than that from raw milk, which is probably due to the incorporation of denatured whey proteins into the curd. According to Lau et al. (1990) pasteurization $\left(63^{\circ} \mathrm{C}\right.$ for $\left.30 \mathrm{~min}\right)$ has little effect on fat recovery in cheese but $\mathrm{N}$ recovery is improved, and approximately 5\% of the whey proteins are associated with casein micelles after pasteurization, resulting in an increased theoretical cheese yield.

During conventional homogenization, the fat globule size is reduced, the fat surface area increases markedly, and a new adsorbed layer consisting of milk proteins (mainly casein micelles and casein subunits and whey proteins) is formed around the fat globules (Cano-Ruiz and Richter, 1997). Our results showed a marked reduction of both volume- and surface-weighted mean diameters, from 2.9 to $0.5 \mu \mathrm{m}$ and 0.6 to $0.3 \mu \mathrm{m}$, respectively.
It has been reported that homogenization processes do not affect the distribution of calcium in milk (Robson and Dalgleish, 1984). In our study, the amount of Ca, $\mathrm{P}$, and $\mathrm{Mg}$ in whey of homogenized-pasteurized milks did not differ from those of pasteurized milks.

Homogenized-pasteurized milks presented lower RCT than raw and pasteurized milks, results that have also been observed by other authors (Robson and Dalgleish, 1984; Ghosh et al., 1994; Guinee et al., 1997). The lower RCT of homogenized milks could be explained by the fact that most $\kappa$-casein is located on the micelle surface. As the casein enrobes the fat globules, the $\kappa$ casein level is effectively diluted and a smaller critical level of $\kappa$-casein hydrolysis is required to start coagulation (Guinee et al., 1997). Furthermore, homogenization increases the surface area of casein by a spreading process, $\kappa$-casein being more available for chymosin action, and thus, reducing RCT (Ghosh et al., 1994).

In the current study, the CF of homogenized milks was reduced by approximately $23 \%$ compared with untreated milk. The weaker gels from homogenized-pasteurized milks could be attributed, according to different authors (Humbert et al., 1980; Robson and Dalgleish, 1984; Ghosh et al., 1994), to a greater dispersion of fat in the curd, to a reduced number of casein particles available to form a strong network because some of the casein is tied to the surface of the new formed fat globules, or to the small fat globules that are entrapped in the gel disrupting the continuity of gel structure and acting as weak centers in the gel. Confocal laser scanning microscopy revealed fat globules embedded within the protein matrix resulting in thick and lumpy strands and a concomitant coarser texture.

Compared with single pasteurization, the homogenization-pasteurization treatment produced higher $(P<$ 0.05 ) amounts of denatured $\beta$-LG and significantly increased the moisture content of the curd. Homogenization of milk resulting in slower whey drainage of the curd has been observed by several researchers (Humbert et al., 1980; Green et al., 1983; Ghosh et al., 1994). The effects of homogenization on the moisture content of the curd have been attributed to the higher incorporation of denatured $\beta$-LG and the alteration in the protein-fat structure of the curd.

\section{Effects of UHPH Treatments}

In accordance with Hayes and Kelly (2003a), smaller fat globules were obtained by applying pressures below $200 \mathrm{MPa}$ at the second valve. Thus, the second valve would act as the secondary stage of a normal homogenizer; that is, stopping or decreasing coalescence. Many studies have shown that above a critical pressure, there is an increased susceptibility of fat globule coalescence 
(Floury et al., 2000, 2004b; Desrumaux and Marcand, 2002). Above $200 \mathrm{MPa}$, the secondary stage not only increased the average size of particles but also widened the distribution; that is, higher heterogeneity, compared with single-stage homogenization. This may be due to partial agglomeration of very small, insufficiently coated globules that collide within the second valve. Thiebaud et al. (2003) detected very small fat globules (40- to 60-nm droplets) in single-stage UHPHtreated milk at 200 and $300 \mathrm{MPa}$, and the impact forces that act on the droplets as the result of a collision have been determined as sufficient to cause disruption of the interfacial membranes (Floury et al., 2000). A broadening of the size distributions was observed for singlestage UHPH of warmed milk (Thiebaud et al., 2003), and model oil-in-water emulsions (Floury et al., 2000) at $300 \mathrm{MPa}$. The formation of large particles was attributed to unfolding and aggregation of whey proteins of the newly created droplets. In our case, 2-stage UHPHtreated milks at $330 \mathrm{MPa}$ showed much broader size distributions. Confocal laser scanning microscopy of rennet gels revealed that this phenomenon was due to the aggregation of well-defined small fat globules within dense proteinaceous structures (Figures $1 \mathrm{~g}$ and $\mathrm{h}$ ).

Milks UHPH-treated below $200 \mathrm{MPa}$ showed similar gel strength compared with homogenized-pasteurized milk. In fact, the protein matrices of the rennet gels observed by confocal microscopy were very similar to those of homogenized-pasteurized gels; that is, thick and lumpy strands giving a rough texture to the matrix (Figures 1a and b). However, their coagulation times were lower than those of homogenized-pasteurized milks. This decrease could be attributed to the lower $\mathrm{pH}$ of UHPH-treated milks, which would enhance chymosin performance. At these pressures, the temperature during processing never exceeded $60^{\circ} \mathrm{C}$. Thus, the decrease in $\mathrm{pH}$ could be attributed to the action of residual indigenous lipoprotein lipase after UHPH treatment. Treatment with UHPH increased the interfacial fat surface by decreasing the average size of particles, which would lead to a greater potential for lipolysis to occur (Hayes and Kelly, 2003a; Hayes et al., 2005).

Mineral equilibrium in milk is very dependent on physicochemical parameters; that is, $\mathrm{pH}$ and temperature. The distribution of ions between the different fractions of milk (diffusible and nondiffusible) is defined by the balance between these factors. The $\mathrm{pH}$ of milks treated at 100 to $130 \mathrm{MPa}$ could be, to some extent, responsible for the higher amounts of minerals in their whey. As $\mathrm{pH}$ decreases, the acido-basic groups of milk constituents become more protonated; hence, micellar calcium phosphate and the small amount of magnesium associated to casein micelles are dissolved (Gaucheron, 2005).

Single-stage UHPH above $200 \mathrm{MPa}$ produced the smallest particles with the narrowest distributions. A further reduction of fat globule size and the increase in interfacial fat surface would lead to a higher adsorption of casein and whey proteins to the newly formed fat globules. Sandra and Dalgleish (2005) reported a decreased micelle average size in skimmed milk by increasing UHPH pressure. They suggested that UHPH would not cause complete disruption of the casein micelles but rather dissociate parts of their surfaces. The obtained particle distributions corroborated that casein micelle fragments, rather than intact casein micelles, would surround fat globules (Hayes et al., 2005). Thus, very small fat globules would behave as casein micelles rather than embedded fat globules observed in normal homogenization or lower UHPH pressures. Such structures could enhance gel firmness and rate of aggregation by increasing the amount of particle associations; hence, leading to the higher RCF and $\mathrm{CF}$ values observed for milk UHPH-treated at 200 and $300 \mathrm{MPa}$. Confocal micrographs of rennet milks treated at 200 and $300 \mathrm{MPa}$ showed lower levels of Nile red fluorescence at the level of the proteinaceous network (Figures $1 \mathrm{c}$ and $\mathrm{d}$ ). This could be explained by the fact that more than $50 \%$ of their particles were beyond the resolution threshold $(0.23 \mu \mathrm{m} /$ pixel $)$.

In early studies on UHPH, no denaturation of whey proteins was reported (Hayes and Kelly, 2003a; Sandra and Dalgleish, 2005). However, the temperature of the process in these studies never exceeded $55^{\circ} \mathrm{C}$. Our temperature values during UHPH treatments were much higher (from $\sim 55$ to $95^{\circ} \mathrm{C}$ ), presumably because of different experimental designs (i.e., a much higher flow rate and relatively larger volumes of milk being processed). If only heat effect is considered, at $\sim 65^{\circ} \mathrm{C}$, whey proteins start to denature and interact with casein micelles (Singh, 1993). However, in UHPH, simultaneous heating and homogenization processes exist. In fact, Hayes et al. (2005), treating warmed milk up to $250 \mathrm{MPa}$ that reached $83.6^{\circ} \mathrm{C}$, suggested that the physical forces experienced by whole milk during UHPH also denatured $\beta$-LG. Our results showed that the amount of denatured $\beta$-LG was much greater (17\%) for UHPHtreated at $200 \mathrm{MPa}$, which reached approximately $75^{\circ} \mathrm{C}$ for a very short time $(\sim 0.7 \mathrm{~s})$, than for pasteurized milk at $72^{\circ} \mathrm{C}$ for $15 \mathrm{~s}$. Such results corroborate the idea that not only heat but also homogenization forces induce the denaturation of whey proteins. Increasing the pressure led to higher recovery of $\mathrm{N}$ in curd with lower levels of residual $\beta$-LG and $\alpha$-LA in the whey.

As previously mentioned, both the $\mathrm{pH}$ of the milk and the temperature reached during the treatment affected 
the mineral equilibrium. Moreover, UHPH produces partial disruption of casein micelles (Sandra and Dalgleish, 2005) that could lead to a transfer of calcium and inorganic phosphate from the micellar to the diffusible fraction. The balance between these factors could explain the differences observed between the treatments at 200 and $300 \mathrm{MPa}$. The fact that whey from milk treated at $200 \mathrm{MPa}$ showed higher amounts of calcium than whey from homogenized-pasteurized milk could be explained by both the release due to disruption of casein micelles and its slightly lower $\mathrm{pH}$ value. In contrast, the amount of minerals in whey from milk UHPHtreated at $300 \mathrm{MPa}$, which was lower than those of the other treatments, suggests a mineral transfer from soluble to colloidal phase due to heat during UHPH treatment.

As pressure was increased, the RCT of milks was prolonged. The differences between RCT at 200 and $300 \mathrm{MPa}$ could be explained by the relative effect of the following factors: 1 ) the spreading of $\kappa$-casein; that is, higher availability and lower critical level for chymosin action; 2) denaturation of $\beta$-LG; that is, steric hindrance; 3) the $\mathrm{pH}$ of milk; and 4) changes in the concentration of calcium between soluble and colloidal phases.

Increasing UHPH pressure led to a higher recovery of $\mathrm{N}$ with lower levels of residual $\beta$-LG and $\alpha$-LA in whey, and higher TS yield and moisture content of curds. The observed differences between treatments could be explained by variations in 1) the association of denatured whey proteins to the surface of casein micelles, 2) the reduction of fat globule size, 3) the incorporation of denatured whey proteins and casein micelle fragments at the fat globule membrane, and 4) the microstructure of the resulting gels. The association of whey proteins at the micelle surface by heat sterically impedes the fusion of rennet-altered micelles resulting in less shrinkage of the paracasein network (Singh and Waungana, 2001). Moreover, the incorporation of denatured whey proteins into the gel matrix increases the water-binding capacity of the paracasein-whey network (Singh and Waungana, 2001). The reduction of fat globule size implies a dispersion of fat into an increased number of smaller globules. The newly built surfaces are modified by the presence of adhering casein particles and become part of the paracasein network, thus hindering shrinkage of the network (Walstra et al., 1985). The water-holding capacity of curds is directly linked to the microstructure of the gels; that is, porosity or permeability (Green et al., 1983; Walstra et al., 1985; Lucey et al., 2001). Green et al. (1983) observed that curds from conventionally homogenized milk had a less coarse protein network, which retained moisture more effectively than curds from nonhomogenized milks. Greater firmness, attributed to greater protein content and cross-linking of casein by denatured whey proteins, leads to higher volume of the network relative to that of the interstices, and thus a reduction of the relative ease of movement of the strands in the protein network (Green et al., 1983; Lucey et al., 2001).

As already stated, 2-stage UHPH above $200 \mathrm{MPa}$ led to greater average particle size and higher heterogeneity than single-stage treatments. The obtained rennet gels showed similar firmness to those of homogenizedpasteurized and 100 to $130 \mathrm{MPa}$ UHPH-treated milks. Confocal microscopy revealed a higher number of fat globules embedded within the proteinaceous matrix giving a rougher texture to the gels than in single-stage UHPH (Figures 1e and f). These results corroborate the hypothesis that 1) embedded fat globules, which lead to thicker strands and a concomitant coarser matrix, are responsible for weaker gels, and 2) the presence of very small fat globules behaving as casein micelles results in stronger rennet gels.

\section{CONCLUSIONS}

The results of this study show that UHPH treatment of milk reduced fat globule size, increased the wet yield of curd and its moisture content, and decreased the protein content of whey. The rennet coagulation properties were enhanced by single-stage UHPH at 200 and $300 \mathrm{MPa}$. However, taking curd firmness into account, the application of a secondary stage produced weaker gels similar to those obtained by conventional homogenization-pasteurization. The improvement of cheesemaking properties of milk by UHPH could be attributed to the combined effect of homogenization (i.e., reduction of particle size) and heat (i.e., denaturation of whey proteins) on the protein-fat structures of the milk.

\section{ACKNOWLEDGMENTS}

The authors acknowledge the Ministerio de Educación y Ciencia (AGL2004-01943) and the Commission of the European Communities (EU project 512626) for the financial support given to this investigation. Anna Zamora acknowledges the predoctoral fellowship from the Ministerio de Educación y Ciencia and the technological support from J. M. Quevedo.

\section{REFERENCES}

Briñez, W. J., A. X. Roig-Sagués, M. M. Hernández Herrero, and B. Guamis López. 2006. Inactivation of Listeria innocua in milk and orange juice by ultrahigh-pressure homogenization. J. Food Prot. 69:86-92.

Cano-Ruiz, M. E., and R. L. Richter. 1997. Effect of homogenization pressure on the milk fat globule membrane proteins. J. Dairy Sci. 80:2732-2739. 
Dalgleish, D. G., and J. M. Banks. 1991. The formation of complexes between serum proteins and fat globules during heating of whole milk. Milchwissenschaft 46:75-78.

Datta, N., M. G. Hayes, H. C. Deeth, and A. L. Kelly. 2005. Significance of frictional heating for effects of high pressure homogenization on milk. J. Dairy Res. 72:1-7.

Desrumaux, A., and J. Marcand. 2002. Formation of sunflower oil emulsions stabilized by whey proteins with high-pressure homogenization (up to $350 \mathrm{MPa}$ ): Effect of pressure on emulsion characteristics. Int. J. Food Sci. Technol. 37:263-269.

Emmons, D. B., M. Kalab, and E. Larmond. 1980. Milk gel structure. $\mathrm{X}$. Texture and microstructure in Cheddar cheese made from whole milk and from homogenized low-fat milk. J. Texture Stud. 11:15-34.

Floury, J., J. Bellettre, J. Legrand, and A. Desrumaux. 2004a. Analysis of a new type of high pressure homogenizer. A study of the flow pattern. Chem. Eng. Sci. 59:843-853.

Floury, J., A. Desrumaux, and J. Lardières. 2000. Effect of highpressure homogenization on droplet size distributions and rheological properties of model oil-in-water emulsions. Innov. Food Sci. Technol. 1:127-134.

Floury, J., J. Legrand, and A. Desrumaux. 2004b. Analysis of a new type of high pressure homogenizer. Part B. study of droplet breakup and recoalescence phenomena. Chem. Eng. Sci. 59:1285-1294.

Gaucheron, F. 2005. The minerals of milk. Reprod. Nutr. Dev. 45:473-483.

Ghosh, B. C., A. Steffl, J. Hinrichs, and H. G. Kessler. 1994. Rennetability of whole milk homogenized before or after pasteurization. Milchwissenschaft 49:363-367.

Green, M. L., R. J. Marshall, and F. A. Glover. 1983. Influence of homogenization of concentrated milks on the structure and properties of rennet curds. J. Dairy Res. 50:341-348.

Guinee, T. P., D. J. O'Callaghan, P. D. Pudja, and N. O'Brien. 1996. Rennet coagulation properties of retentates obtained by ultrafiltration of skim milks heated to different temperatures. Int. Dairy J. 6:581-596.

Guinee, T. P., C. B. Gorry, D. J. O'Callaghan, B. T. O'Kennedy, N. O'Brien, and M. A. Fenelon. 1997. The effects of composition and some processing treatments on the rennet coagulation properties of milk. Int. J. Dairy Technol. 50:99-106.

Hayes, M. G., P. F. Fox, and A. L. Kelly. 2005. Potential applications of high pressure homogenization in processing of liquid milk. J. Dairy Res. 72:25-33.

Hayes, M. G., and A. L. Kelly. 2003a. High pressure homogenization of raw whole bovine milk: (a) effects on fat globule size and other properties. J. Dairy Res. 70:297-305.

Hayes, M. G., and A. L. Kelly. 2003b. High pressure homogenization of milk: (b) effects on indigenous enzymatic activity. J. Dairy Res. 70:307-313.

Humbert, G., A. Driou, J. Guerin, and C. Alais. 1980. Effets de l'homogénisation à haute pression sur les propriétés du lait et son aptitude à la coagulation enzymatique. Lait 599/600:574-594.

IDF. 1987. Milk, cream and evaporated milk - Determination of total solids content. IDF Standard 21B:1987. International Dairy Federation, Brussels, Belgium.
IDF. 2002. Milk and milk products - Determination of nitrogen content. IDF Standard 185:2002/ISO 14891. International Dairy Federation, Brussels, Belgium.

Jana, A. H., and K. G. Upadhyay. 1992. Homogenization of milk for cheesemaking - A review. Aust. J. Dairy Technol. 47:72-79.

Jelen, P., and W. Rattray. 1995. Thermal denaturation of whey proteins. Pages 66-85 in Heat induced changes in milk. 2nd ed. P. F. Fox, ed. International Dairy Federation, Brussels, Belgium.

Lau, K. Y., D. M. Barbano, and R. R. Rasmussen. 1990. Influence of pasteurization on fat and nitrogen recoveries and Cheddar cheese yield. J. Dairy Sci. 73:561-570.

Lucey, J. A. 1995. Effect of heat treatment on the rennet coagulability of milk. Pages 171-187 in Heat induced changes in milk. 2nd ed. P. F. Fox, ed. International Dairy Federation, Brussels, Belgium.

Lucey, J. A., M. Tamehana, H. Singh, and P. A. Munro. 2001. Effect of heat treatment on the physical properties of milk gels made with both rennet and acid. Int. Dairy J. 11:559-565.

Macheboeuf, D., J. B. Coulon, and P. D'Hour. 1993. Effect of breed, protein genetic variants and feeding on cows' milk coagulation properties. J. Dairy Res. 60:43-54.

Michalski, M. C., R. Cariou, F. Michel, and C. Garnier. 2002. Native vs. damaged milk fat globules: Membrane properties affect the viscoelasticity of milk gels. J. Dairy Sci. 85:2451-2461.

Pearse, M. J., and A. G. MacKinlay. 1989. Biochemical aspects of syneresis: A review. J. Dairy Sci. 72:1401-1407.

Resmini, P., L. Pellegrino, R. Andreini, and F. Prati. 1989. Determinazione delle sieroproteine solubili del latte per HPLC (cromatografia liquida ad alta prestazione) in fase inversa. Sci. Tecn. Latt. Cas. 40:7-23.

Robson, E. W., and D. G. Dalgleish. 1984. Coagulation of homogenized milk particles by rennet. J. Dairy Res. 51:417-424.

Rynne, N. M., T. P. Beresford, A. L. Kelly, and T. P. Guinee. 2004. Effect of milk pasteurization temperature and in situ whey protein denaturation on the composition, texture and heat-induced functionality of half-fat Cheddar cheese. Int. Dairy J. 14:9891001.

Sandra, S., and D. G. Dalgleish. 2005. Effects of ultra-high-pressure homogenization and heating on structural properties of casein micelles in reconstituted skim milk powder. Int. Dairy J. 15:1095-1104.

Singh, H. 1993. Heat induced interactions of proteins in milk. Pages 191-204 in Protein and fat globule modifications by heat treatment, homogenization and other technological means for high quality dairy products. Proc. IDF Seminar, Munich, Germany. International Dairy Federation, Brussels, Belgium.

Singh, H., and A. Waungana. 2001. Influence of heat treatment of milk on cheesemaking properties. Int. Dairy J. 11:543-551.

Thiebaud, M., E. Dumay, L. Picart, J. P. Guiraud, and J. C. Cheftel. 2003. High-pressure homogenization of raw bovine milk. Effects on fat globule size distribution and microbial inactivation. Int. Dairy J. 13:427-439.

Walstra, P., H. J. M. van Dick, and T. J. Geurts. 1985. The syneresis of curd. 1. General considerations and literature review. Neth. Milk Dairy J. 39:209-246. 